\title{
Performance evaluation of self propelled rotary weeder
}

\section{G.S. PATANGE, P.J. THOKALE AND V.D. DESHMUKH}

Received : 09.01.2015; Revised : 23.02.2015; Accepted : 07.03.2015

See end of the Paper for authors' affiliation

Correspondence to :

G.S. PATANGE

Farm Machinery Testing,

Training and Production

Centre, AICRP on FIM,

Mahatma Phule Krishi

Vidyapeeth, Rahuri,

AHMEDNAGAR (M.S.) INDIA

Email : gspatange.iitkgp@

gmail.com
- ABSTRACT : Weed control is one of the most essential and expensive operation in crop production. The conventional methods of weeding viz., manual and animal drawn involve drudgery, time loss and also increase the cost of operation. Manual weeding is common in Indian agriculture. It is the most widely used weed control method but it is labour intensive. The use of mechanical weeder will reduce drudgery and ensure a comfortable posture of the farmer or operator during weeding. This will resultantly increase production. Average depth and width of operation of developed machine was $14 \mathrm{~cm}$ and $110 \mathrm{~cm}$, respectively. The performance evaluation of machine was calculated on the basis of three different engine speeds i.e. 2180, 2752, $2905 \mathrm{rpm}$ and results showed that, field efficiency of 51.3, 64.96, 72.73 per cent was with fuel consumption of $0.81,1.19$, $1.68 \mathrm{lt} . / \mathrm{hr}$, respectively with weeding efficiency of 53.4, 63.73, 72.11 per cent. Thus, this weeder was found to be beneficial on the basis of weeding efficiency and operating time.

- KEY WORDS : Performance, Self propelled, Rotary weeder

- HOW TO CITE THIS PAPER : Patange, G.S., Thokale, P.J. and Deshmukh, V.D. (2015). Performance evaluation of self propelled rotary weeder. Internat. J. Agric. Engg., 8(1) : 70-74. 